\title{
Dolaylı-Dolaysız Vergiler Temelinde Bütçe Dengesinin İktisadi Büyümeye Etkisi: Türkiye ve Almanya Örneği
}

\author{
Aytekin BEKTAŞ \\ T.C. Çevre ve Şehircilik Bakanliğı Milli Emlak Kontrolörü \\ aytekin1980@yahoo.com,ORCID:0000-0002-2888-7542
}

$\ddot{O} \mathbf{z}$

Çalışmanın amacı bütçe dengesindeki değişmelerin iktisadi büyüme üzerindeki etkisinin ortaya konulmasıdır. Bu kapsamda Türkiye ve Almanya'daki durum incelenmiştir. Bu ülkelerin seçilme nedeni ise vergi (dolaylı-dolaysız) tercihlerindeki farklılıktır. Nitekim dolaylı vergilerin ağırlığı Türkiye için yaklaşık \%70 düzeyindedir. Bu oran Almanya için ise yaklaşık $\% 45$ düzeyindedir. Çalışmada her iki ülke için 1995-2016 dönemini kapsayan bütçe dengesi ve iktisadi büyüme verileriyle Otoregresif Dağıtılımış Gecikme (ARDL) modeli kullanılarak ekonometrik bulgulara ulaşılmıştır. Bu etki uzun dönemde Türkiye ve Almanya açısından benzerlik göstermektedir. Kısa dönem etkisinde ise önemli farklılıklar bulunduğu tespit edilmiştir. Bütçe dengesinde her \%1 değişim Türkiye için, aynı yönde dönem büyümesine $\% 1,82$, sonraki y1l büyümesine $\% 0,28$ etki yapmaktadır. Bu etki uzun dönemde ise $\% 0,27$ olmaktadır. Almanya için ise bütçe dengesinde her $\% 1$ değişim, aynı yönde dönem büyümesine $\% 0,52$, uzun dönem büyümesine $\% 0,24$ etki yapmaktadır. Ekonometrik bulgulara göre iki ülke açısından da bütçe dengesinin ekonomik büyüme üzerinde etkili olduğu anlaşılmaktadır.

Anahtar Kelimeler: Ekonomik Büyüme, Bütçe Dengesi, ARDL Sınır Testi

JEL Sinıflandirmasi: H20, H62, O40

The Effect of Budget Balance on Economic Growth on the Basis of Indirect-Direct Taxes: The Case of Turkey and Germany ${ }^{1}$

\begin{abstract}
The purpose of this study is to reveal the effect of changes in budget balance on economic growth. In this context, the situation in Turkey and Germany were examined. The reason for the selection of these countries is the difference in tax (indirect-direct) preferences. Indeed, the weight of indirect taxes is about $70 \%$ for Turkey. This rate is about $45 \%$ for Germany. In this study, the econometric findings were obtained by using the Autoregressive Distributed Lag (ARDL) model with budget balance and economic growth data covering the period 1995-2016 for both countries. This effect is similar in terms of Turkey and Germany in the long term. On the other hand, significant differences were observed in the short-term effect. For Turkey, $1 \%$ change in budget balance has an effect of $1.82 \%$ on the same period growth and $0.28 \%$ in the next period. This effect is $0.27 \%$ in the long term. For Germany, $1 \%$ change in budget balance has an effect of $0.52 \%$ on the same period growth and $0.24 \%$ on the long term growth. According to the econometric findings, it is understood that budget balance has an effect on economic growth for both countries.
\end{abstract}

Keywords: Economic Growth, Budget Balance, ARDL Bound Testing

JEL Classification: H20, H62, O40

\footnotetext{
${ }^{1}$ Extended abstract is presented at the end of the article.
} 


\section{Giriş}

Kamu harcamalarının temel finansman kaynağı olan vergilerin, nasıl ve hangi kaynaklar üzerinden elde edileceği ülkelerin gelişmişlik seviyesine göre farklılık gösterebilir. Gelişmiş ülkelerde vergi sisteminin adaletli olması temel hedef olduğundan vergi kompozisyonu da bu çerçevede dolaysız vergi ağırlıklı bir yapı göstermektedir. Gelişmekte olan ülkelerde ise kaynak oluşturma ihtiyacı ülkeleri daha kolay gelir elde edilebilir kaynaklara yöneltmekte ve bu çerçevede vergi sistemi dolaylı vergilere ağırlık veren bir yapı sergilemektedir.

Genel olarak ifade edilecek olursa, maliye politikası doğrultusunda belirlenen dolaysız vergiler kişilerin ve kurumların gelirleri ile servet unsurları üzerine odaklanırken, dolaylı vergiler ağırlıklı olarak ekonomik birimlerce gerçekleştirilen harcamalar üzerine odaklanmaktadır. Doğal olarak ülkeler bakımından uygulanacak olan dolaylı ve dolaysız vergilerin ihtiyaçlar çerçevesinde birbirlerine göre tercih edilme nedenleri bulunabilmektedir. Örneğin, bazı ülkelerde kişilerin vergi ödeme güçlerine göre vergilendirilmeleri suretiyle vergilemede adalet ilkesinin sağlanması ve toplumdaki kişisel gelir dağılımının daha adil hale getirilmesi gayesiyle dolaysiz vergiler tercih edilirler. Benzer şekilde takip, tahsil ve idaresinin kıyasen daha kolay olması nedeniyle dolaysız vergiler, buna karşın siyasi riskinin göreceli olarak daha düşük olması nedeniyle dolaylı vergiler tercih edilebilmektedir.

Bir ülkede uygulanmakta olan dolaylı vergiler ile dolaysız vergilerin bileşiminin o ülkedeki bireylerin tüketim, tasarruf, yatırım, çalışma gibi tercihleri üzerinde etkili bir faktör olduğu muhakkaktır. Vergilendirme tercihleri üzerinden ortaya çıkabilecek olan bu farklılıklar ise iktisadi büyüme üzerinde etkili olabilmektedir. Nitekim dolaylı vergilerdeki bir artış o toplumu oluşturan bireylerin tüketim alışkanlıkları üzerinde etkili olarak ikame mallara yönelme isteğinin yanı sıra tüketim ile tasarruf alışkanlıklarını da etkileyebilecektir. Benzer şekilde dolaysız vergilerdeki bir artış bireylerin tasarruf ve yatırım isteğini azaltırken çalışarak üretme isteğini de aşınmaya uğratabilecektir. Bu durumun ortaya çıkmasındaki temel neden ise dolaysız vergilerin akım olarak geliri, stok olarak da servet unsurlarını vergi konusu yapmasıdır. Dolaylı ve dolaysız vergilerin etkileri burada belirtilmiş olanlarla sınırlı olmamakla beraber temel anlamıyla dolaysız vergilerin bir ülkedeki iktisadi büyüme üzerindeki etkilerinin dolaylı vergilere göre daha geniş çaplı olduğu söylenebilir. Bu çerçevede bir ülkedeki bütçe dengesinin büyüme üzerinde ortaya çıkarmış olduğu etki düzeyinde o ülkedeki dolaylıdolaysız vergi ağırlığının da göz önünde bulundurulması gereken önemli bir etken olduğu düşünülmektedir.

Literatürde yer alan çalışmalara bakıldığında, iktisadi büyüme ile bütçe dengesi arasındaki ilişkiyi değişik dönemler itibariyle birden fazla ülke açısından ele alan araştırmaların bulunduğu görülmektedir. Benzer şekilde bu çalışma kapsamında da bir ülkedeki iktisadi büyüme ile bütçe dengesi arasındaki ilişki ortaya 
konulmaya çalışılacaktır. Burada ilişkinin somutlaştırılması anlamında dolaylı ve dolaysız vergi tercihlerinde birbirinden ayrıştığg gözlemlenen iki ülke belirlenmiş olması ve söz konusu ilişkinin varlığının belirlenmiş dönem için bu anlamda irdelenmesi çalışmanın ayrıştığı ve katkı sağlayacağ noktaya işaret etmektedir. $\mathrm{Bu}$ ülkelerden birincisi toplam vergi gelirleri içerisinde dolaylı vergilerin payının göreceli olarak oldukça yüksek olduğu Türkiye'dir. Nitekim OECD verilerine bakıldığında, Türkiye'de özellikle 2000'li yılların başından itibaren dolaylı vergilerin vergi sistemi içerisindeki ağırlığının daha da artarak ortalama \%70 düzeyine ulaşmış olduğu görülmektedir. Çalışma için ikinci ülke olarak ise Almanya ele alınmıştır. $\mathrm{Bu}$ ülkenin seçilmiş olmasının temel nedeni ise Türkiye'de mevcut olanın aksine vergi sisteminde dolaysız vergilerin ağırlıklı bir görünüm arz etmesidir. Öyle ki yine OECD verilerine bakıldığında incelenen dönem itibariyle Almanya'da dolaylı vergilerin vergi sistemi içerisindeki ağırlığının ortalama olarak \%45 ile \%50 arasında değişmekte olduğu görülmektedir (OECD, 2017).

Çalışmayla ilgili olarak vurgulanması gereken önemli bir husus ise Türkiye ile Almanya örnekleri üzerinden iktisadi büyüme ve bütçe dengesi arasındaki ilişkinin ele alınması amaçlanmakta olup bunun ötesinde iki ülke arasında birebir bir karşılaştırma yapma düşüncesinin var olmayışıdır. Kaldı ki ülkeler arasındaki gelişmişlik düzeyi farklılıkları ile yapısal ayrışmalar bu konuda birebir bir karşılaştırmaya da olanak vermemektedir.

\section{Kavramsal Altyapı ve Genel Çerçeve}

\subsection{Vergi Yapis1}

Kamu hizmetlerinin finansmanını sağlamak amacıyla gereken kaynakları oluşturmak ve bazı ekonomik ve sosyal amaçları gerçekleştirmek üzere egemen kamu otoritesi tarafından kişilerden kamu gücüne dayanılarak alınan pay olan vergi dışında gelir kaynakları olmakla beraber vergi gelirleri kamu harcamalarının en önemli finansman kaynağını oluşturmaktadır (Oktar, 2010, s. 4).

Vergi sistemi içerisinde var olan vergiler değişik ölçütlere göre farklı şekillerde gruplandırılabilir. Konularına, tahsilatı yapan idari birimlere, ödeme şekillerine, tarifelerine, mükelleflerin kişisel ve ailevi durumlarını göz önünde bulundurmalarına, kapsamlarına ve uygulama sürelerine göre gruplandırma bunlardan bazılarıdır. Bir diğer gruplandırma ise vergilerin dolaylı ya da dolaysız nitelikte olmalarıdır (Akdoğan, 2007, s. 247). Bu çalışma kapsamında ele alınan ülkelerin vergi sisteminde yer alan vergilerin temel ayrım kriteri dolaylı ya da dolaysız nitelik taşımaları olmuş ve konu bu çerçevede ele alınmıştır.

Teori ve uygulama anlamında vergilerin dolaylı ya da dolaysız olarak gruplandırılmalarında iki temel ölçüt bulunmaktadır. Bunlardan birincisi yansıma özelliğinin var olup olmadığı, yani vergi yükünün mükellef tarafından başkalarına 
aktarılıp aktarılamayacağ 1 , ikincisi ise verginin devamlılığı ve tahsil usulü meselesidir (Akdoğan, 2007, s. 285).

Dolaylı ve dolaysız vergilerin niteliksel anlamda belirgin çizgilerle birbirinden ayrıldığı görülmektedir. Örneğin; dolaylı vergiler mal ve hizmetler üzerindeki alım satım gibi bir işleme uygulanırken dolaysız vergiler işlemden bağımsız olarak gelir ve servet unsurlarına odaklanırlar, dolaylı vergilerde dolaysız vergilerin aksine devletin vergi veya vergi benzeri mali yükümlülükleri fiyat içerisine gizleyerek vergi yükümlüsüne hissettirmeden tahsil etmesini ifade eden mali anestezi durumu kendini göstermektedir. Benzer şekilde dolaylı vergiler genel fiyat ve nispi fiyat düzeyini etkilerken dolaysız vergiler etkilemez, dolaylı vergiler kişilerin şahsi durumları ile ödeme güçlerini göz ardı ederken dolaysız vergiler aksine bunları temel alır, dolaysız vergilerde istisnai durumlar dışında vergi yükü mükellef konumunda bulunan kişi ya da kurum üzerinde kalmakta iken dolaylı vergilerde bu yük yansıtılır.

Uygulanacak dolaylı ve dolaysız vergilerin birbirine göre var olan üstün durumlarının bulunduğunu söylemek doğru bir ifade olacaktır. Öyle ki dolaysız vergiler sübjektif nitelikleri göz önünde bulundurduğu için daha adil bir vergileme sistemi sağlarken dolaylı vergiler tahsilatı kolay ve kıyasen daha az masraflı tahsil edilebildikleri için siyasal karar mekanizmalarınca daha öncelikli olarak tercih edilirler. Elbette dolaylı vergilerin daha fazla tercih edilmesi bazı sıkıntıları da beraberinde getirmektedir. Bu durumun Türkiye açısından ele alınması halinde anayasal bir aykırılığın ortaya çıktığı görülmektedir. Öyle ki Türk vergi sisteminde genel itibarıyla dolaysız vergiler gelir ve kazançlar üzerinden alınan vergiler (gelir vergisi ve kurumlar vergisi) ile mülkiyet üzerinden alınan vergilerden (veraset ve intikal vergisi, motorlu taşıtlar vergisi ve emlak vergisi) oluşmakta iken dolaylı vergiler dâhilde alınan vergiler (en önemlileri KDV ve ÖTV), uluslararası ticaret ve muameleler üzerinden alınan vergiler ile damga vergisi ve harçlardan oluşmaktadır. Bu kapsamda Türkiye'de dolaylı vergilerin, vergi gelirleri içindeki payı her dönem değişmekle birlikte ortalama üçte iki ağırlığa sahip bulunduğu görülmektedir. $\mathrm{Bu}$ ise Anayasa'nın vergi ödevi konusunu düzenleyen 73'üncü maddesine aykırılık teşkil etmektedir. Söz konusu maddede, "Herkes, kamu giderlerini karşllamak üzere, malî gücüne göre, vergi ödemekle yükümlüdür. Vergi yükünün adaletli ve dengeli dăgllımı, maliye politikasının sosyal amacıdır. " hükmü yer almaktadır.

Çalışma kapsamında vergi yapısına Türkiye ve Almanya için bakıldığında iki ülkenin dolaylı ve dolaysız vergi ağırlığı açısından birbirinden oldukça farklı bir yapıya sahip olduğu görülmektedir. Türkiye'de dolaylı vergiler lehine bir vergilendirme politikası benimsenmiş iken Almanya'daki vergi uygulamalarında dolaysız vergiler ön plana çıkmış durumdadır. Burada ülkeler itibarıyla dolaylı vergiler ile dolaysız vergilerin ağırlığı ortaya konulurken sosyal güvenlik harcamaları hariç tutulmuştur. 
Vergi kompozisyonu y1llar itibarıyla değişiklikler göstermekle birlikte Türkiye'de vergi sistemi içerisinde dolaylı vergilerin ağırlığ $\% 70$ gibi yüksek bir orana tekabül etmektedir. Buna karşın dolaylı vergilerin Almanya vergi sistemi içerisindeki ağırlığı ortalama olarak \%45 düzeyindedir. Örneğin toplam vergi gelirleri içerisinde dolaylı vergiler 2015 yılında Türkiye'de \%68,91, Almanya'da $\% 46,25$ paya; 2014 y1lında Türkiye'de \%67,48, Almanya'da \%46,71 paya; 2013 yılında Türkiye'de \%69,93, Almanya'da \%46,96 paya; 2012 yılında Türkiye'de $\% 67,39$, Almanya'da \%48,12 paya; 2011 yılında Türkiye'de \%68,05, Almanya'da $\% 49,28 ; 2010$ yılında Türkiye'de \%68,01, Almanya'da \%49,91 paya sahip olmuştur (OECD, 2017). Bu veriler 1şığında çalışmada ele alınan 1992-2016 dönemi için her iki ülke açısından dolaylı-dolaysız vergi ağırlığının önemli ölçüde muhafaza edildiğinden bahsedilebilir.

\subsection{Bütçe Dengesi}

Musgrave'e (2004, s. 6) göre mali amaçları kaynak ayırımı, gelir ve servet dağılımının düzeltilmesi ile ekonomik istikrarın sağlanması olan ve Uluatam'a (2005, s. 113) göre yasama organına bir anlamda yürütme organının işlemlerine izin verme ve onu denetleme imkânı veren bütçeye ilişkin denge olgusu,

[Bütçe Dengesi = Kamu Gelirleri - Kamu Giderleri] şeklinde ifade edilebilir.

Bütçenin, kamu giderleri ile kamu gelirleri arasındaki dengeyi yansıtıyor olması nedeniyle bir ülkede bütçe açığının var olması iki büyüklük arasında kamu gelirleri aleyhine bir durum ortaya çıktığını göstermektedir. Benzer şekilde bütçe fazlası durumu ise tam aksine kamu gelirleri lehine bir dengeye işaret etmektedir.

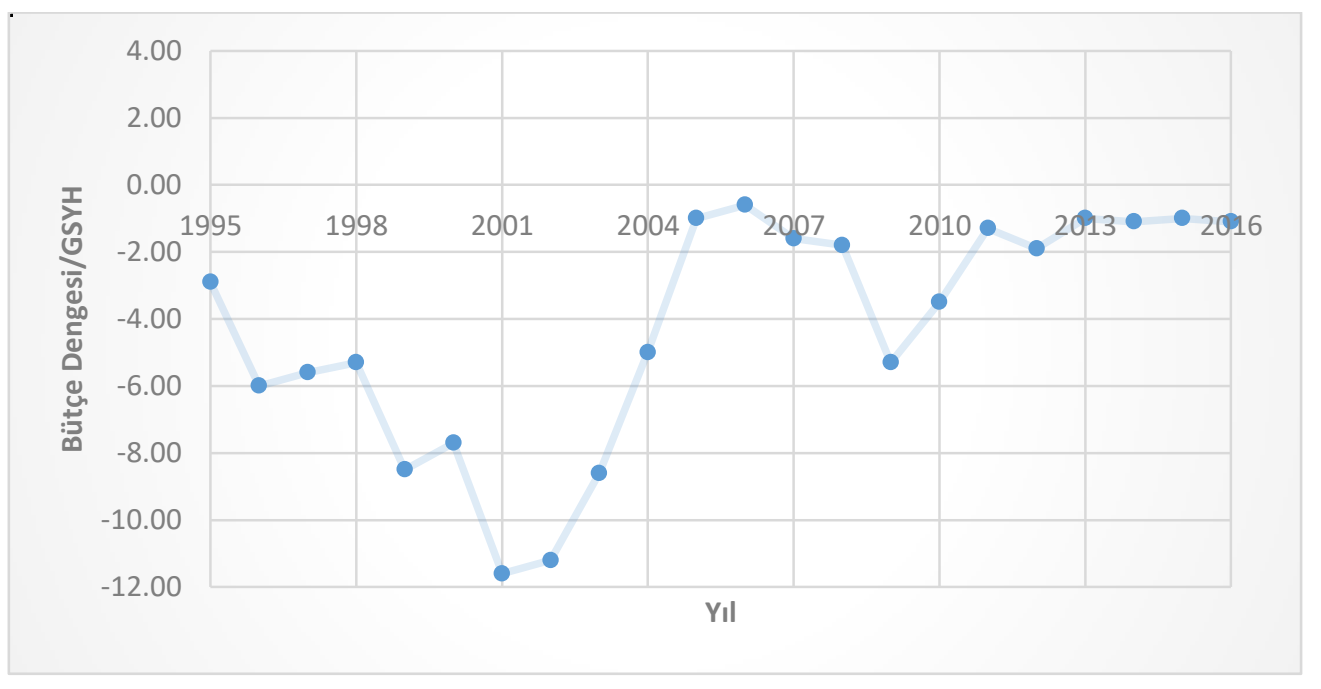

Şekil 1: Türkiye'de Bütçe Dengesinin Gelişimi (1995-2016)

Kaynak: T.C. Hazine ve Maliye Bakanlığından edinilen verilerle oluşturulmuştur. (https://www.hmb.gov.tr/bumko-ekonomik-gostergeler) 
Türkiye'de bütçe dengesinin gelişimine, 1995 ile 2016 yılları arasındaki dönemi yansıtan Şekil 1 üzerinden bakıldığında yıllar itibarıyla bütçe açığı verilmesi yönünde önemli dalgalanmaların yaşandığı görülmektedir. Söz konusu dönemde hiçbir yılda bütçe fazlası verilmemiş olup GSYH'ye göre oransal bazda en büyük bütçe açığıının 2001 yılında \%11,6 ve 2002 yılında \%11,2 olarak gerçekleşmiş olduğu görülmektedir. Diğer taraftan GSYH'ye göre oransal bazda en düşük bütçe açı̆̆ının ise 2006 yılında \%0,6 olarak gerçekleşmiş olduğu anlaşılmaktadır.

Benzer şekilde Almanya ekonomisi bakımından bütçe dengesinin gelişimine 1995 ile 2016 yılları arasındaki dönemi yansıtan Şekil 2 aracılığıyla bakıldığında bu yıllar itibarıyla bütçe dengesinde, Türkiye ekonomisine kıyasla daha küçük dalgalanmaların ortaya çıkmış olduğu açıkça görülmektedir. Söz konusu dönem içerisinde bazı yıllarda bütçe açı̆̆ı verilirken bazı yıllarda ise bütçe fazlası verilmiş olduğu anlaşılmaktadır. Bu kapsamda GSYH'ye göre oransal bazda en büyük bütçe açığının ise 1995 yılında \%9,43 ve 2010 yılında \%4,22 olarak gerçekleşmiş olduğu görülmektedir. Diğer taraftan GSYH'ye göre oransal bazda en büyük bütçe fazlasının ise 2000 yılında $\% 0,86$ ve 2016 yılında $\% 0,82$ olarak gerçekleşmiş olduğu anlaşılmaktadır.

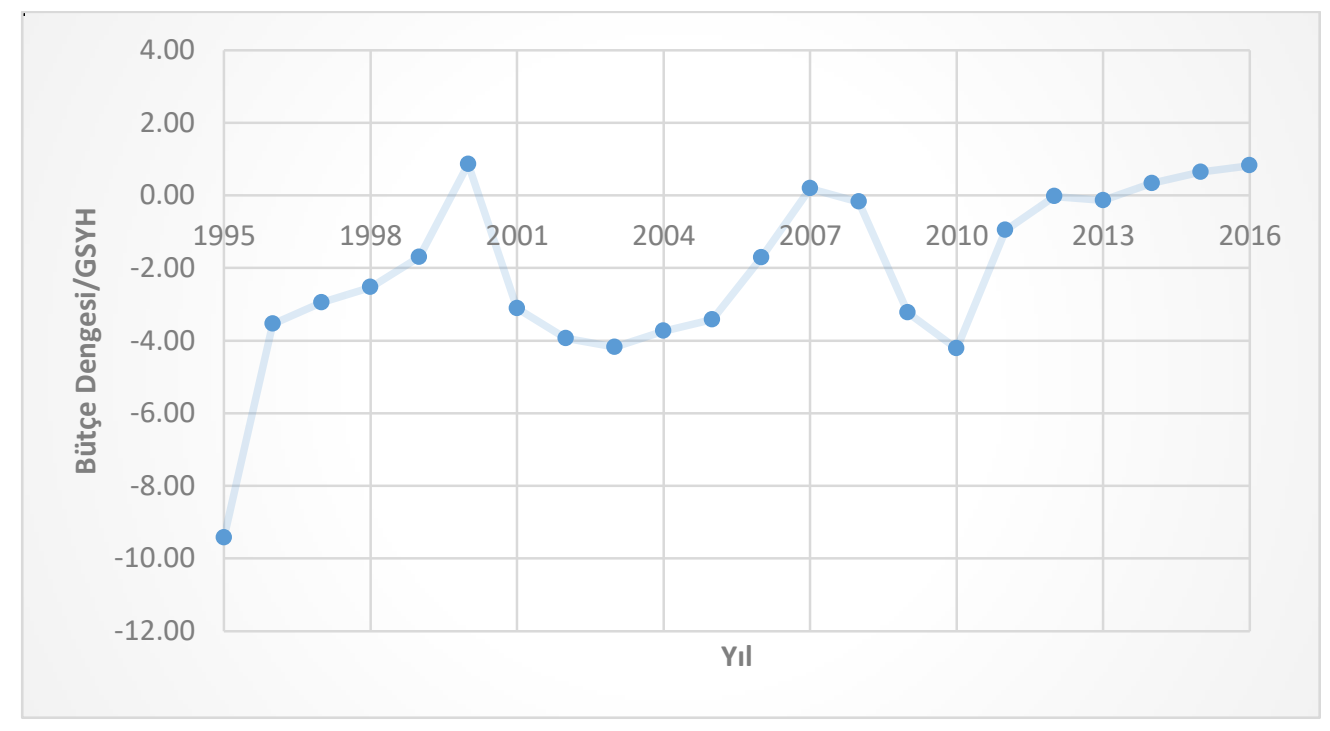

Şekil 2: Almanya'da Bütçe Dengesinin Gelişimi (1995-2016)

Kaynak: OECD verileri kullanılarak yazarca oluşturulmuştur. (https://data.oecd.org/gga/general-government-deficit.htm) 


\section{3. İktisadi Büyüme}

Nominal büyüklüklerin ortaya çıkarabileceği yanıltıcı sonuçlar nedeniyle çalışmaya esas olan 1995 ile 2016 yılları arasında büyüme verilerinin oluşturulmasında ülkelerin reel GSYH (Gayrisafi Yurtiçi Hâsıla) artış oranları temel alınmıştır. İlk olarak Türkiye'de iktisadi büyümenin bu dönemdeki gelişimine Şekil 3 üzerinden bakıldığında 1999, 2001 ve 2009 yılları hariç diğer yıllarda ekonomide pozitif büyüme sağlanmış olduğu görülmektedir. Burada göze çarpan bir durum ise söz konusu dönemde birbirini takip eden yıllarda oldukça farklı büyüme oranlarının ortaya çıkmış olmasıdır. Yıllar itibarıyla Türkiye'de en yüksek iktisadi büyüme 2004 yılında \%9,36 ve 2011 yılında \%10,65 oranında gerçekleşirken, en fazla iktisadi daralmanın 2001 yılında \%6,01 ve 2009 yılında $\% 4,84$ oranında gerçekleşmiş olduğu görülmektedir.

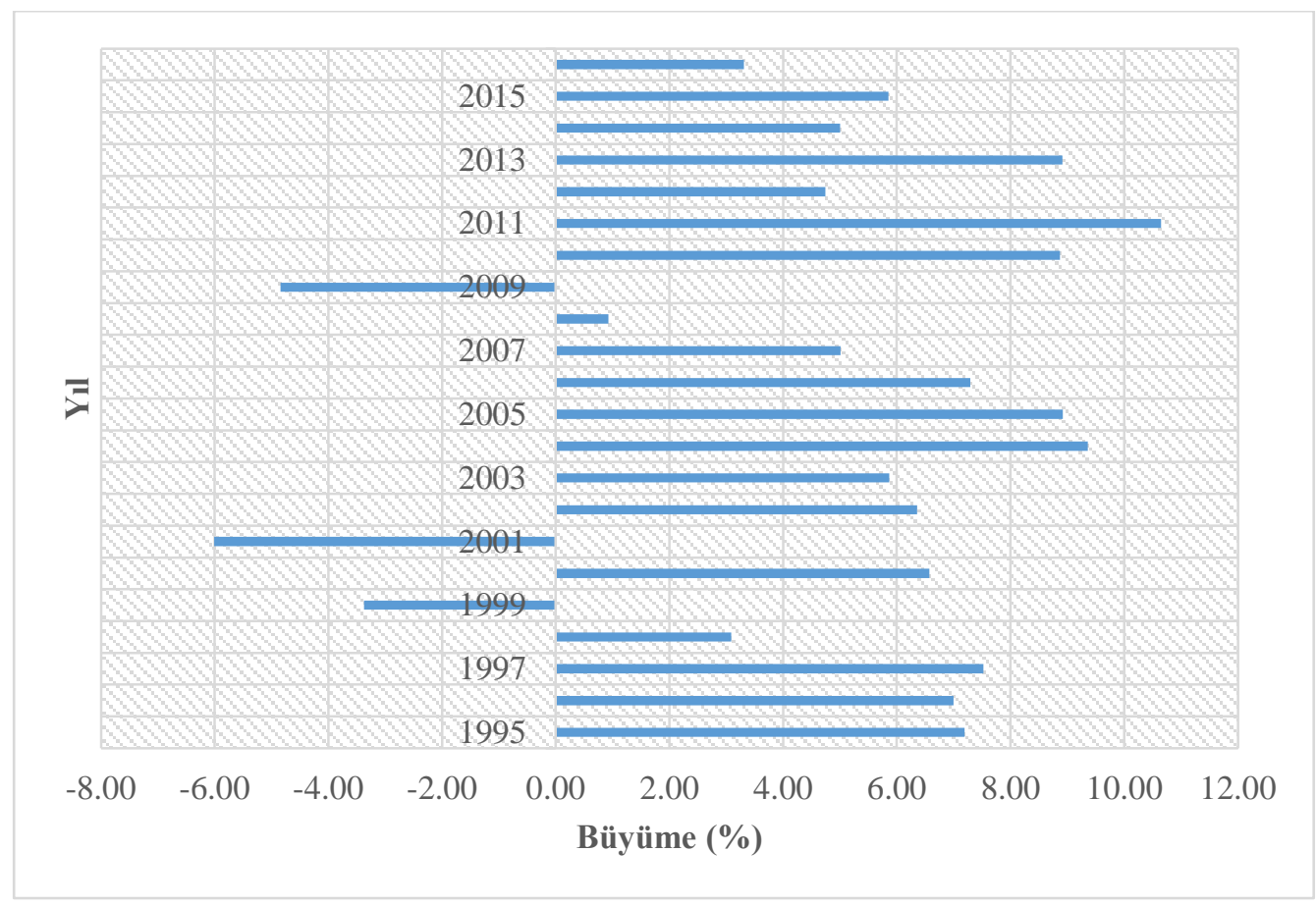

Şekil 3: Türkiye'de Reel GSYH Büyüme Hızı (1995-2016)

Kaynak: OECD verileri kullanılarak yazarca oluşturulmuştur. (Economic Outlook No:102 November 2017, http://stats.oecd.org/)

Benzer şekilde Almanya'da iktisadi büyümenin zaman içerisindeki gelişimine Şekil 4 vasıtasıyla bakıldığında, 2003 yılı ve 2009 yılı hariç olmak üzere diğer yıllarda pozitif büyümenin sağlanmış olduğu görülmektedir. Bu çerçevede Almanya'nın iktisadi büyüme gelişimi noktasında Türkiye'den önemli ölçüde farklılık arz ettiğinden bahsedilebilir. 
Burada Almanya ekonomisinde gerçekleşen iktisadi büyümenin yıllar itibarıyla Türkiye ekonomisine kıyasla daha az dalgalanma gösterdiği ve daha düzenli olduğu net olarak görülmektedir. Almanya'da en yüksek iktisadi büyüme 2010 yllında $\% 3,94$ ve 2006 y1lında $\% 3,87$ oranında gerçekleşirken en fazla iktisadi daralmanın 2009 yilında \%5,56 ve 2003 yilında \%0,72 oranında gerçekleşmiş olduğu görülmektedir.

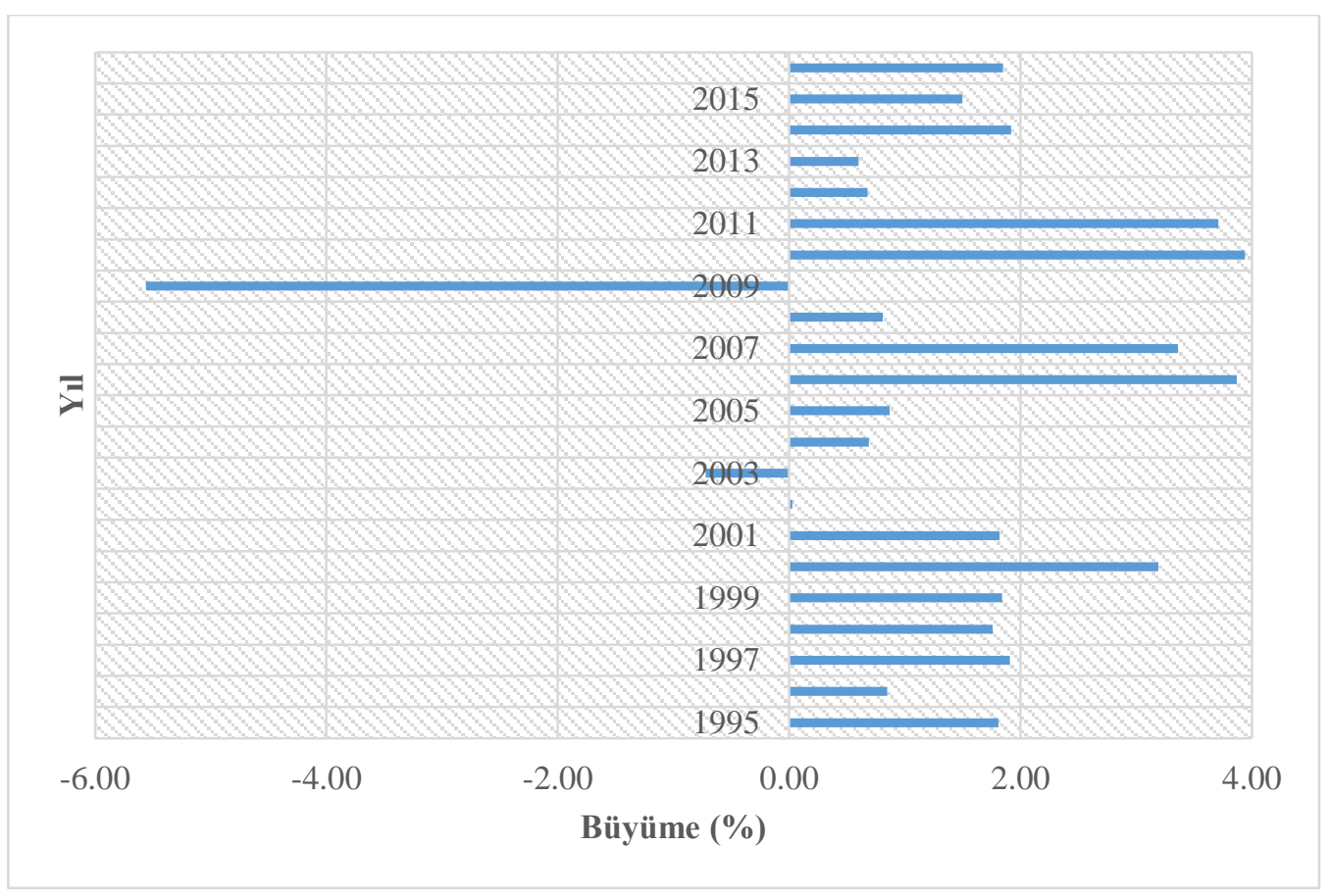

Şekil 4: Almanya'da Reel GSYH Büyüme Hızı (1995-2016)

Kaynak: OECD verileri kullanılarak yazarca oluşturulmuştur. (Economic Outlook No:102 November 2017, http://stats.oecd.org/)

\section{Literatür Taraması}

Bir ülke ekonomisinde bütçe dengesi ile iktisadi büyüme arasındaki ilişkinin farklı açılardan irdelenmesi anlamında bugüne kadar çeşitli çalışmaların yapılmış olduğu ifade edilebilir. Ancak genel itibariyle çalışmaların kamu harcamaları ile iktisadi büyüme arasındaki ilişki üzerine yoğunlaşmış olduğu görülmüştür. Yine çalışmaların önemli bir kısmında öne çıkan başka bir husus ise bu ilişkinin Keynesyen Hipotez ve Wagner Yasası çerçevesinde değerlendirilmiş olmasıdır.

Keynesyen yaklaşıma göre bir ekonomide asıl olan denge durumu değil dengesizlik durumudur ve devletin özellikle kamu harcamaları vasıtasıyla bütçe dengesi üzerinden iktisadi büyümeyi etkileyebilmesi söz konusudur. Bunun en temel nedeni fiyat mekanizmasına dayalı piyasa koşullarında faaliyet gösteren ekonomiler açısından eksik istihdam düzeyinin olağan bir durum arz etmesi ve 
devlet müdahalesi yoluyla büyüme üzerinde olumlu etki yaratılabilmesidir. Keynesyen yaklaşıma göre özellikle ekonominin durağan olduğu ya da daralma yaşadığ 1 dönemlerde bu durumun aşılması bakımından devletin bütçe açığ 1 verme kaygısından uzaklaşarak kamu harcamalarını genişletmesinin gerekli hatta mutlak bir zorunluluk olduğu savunulmaktadır.

Wagner Yasası ise bir ekonomide en azından sanayileşme, altyapı ve sosyal gelişmelerin ön plana çıktığı belirli zamanlarda devlet tarafından sarf edilen kamu harcamalarının o ülkenin milli hasılasından daha yüksek bir artış gösterdiğini ifade etmektedir (Akdoğan, 2007, s. 69). Kamu harcamalarına bakış açısı itibariyle Keynesyen Yaklaşım ile Wagner Yasası'nın en temel farklılığı ise Keynesyen Yaklaşım'da kamu harcamalarının iktisadi büyüme noktasında önemli ve oldukça aktif bir etken olarak ele alınırken, Wagner Yasası'nda kamu harcamalarının aktif bir etken olarak değil bir sonuç olarak ele alınmak suretiyle pasif bir görünüme konumlandırılmış olmasıdır.

Yukarıda bahsi geçen çalışmalardan kendi bünyesi içerisinde ve sistematik bir çerçevede ekonometrik bulgulara yer verilmiş olan bazılarına aşağıda kısaca değinilmiştir.

Barro (1991) tarafından 1960-1985 dönemini kapsayan 98 ülke üzerinde büyüme, doğurganlık ve yatırımlar arasındaki ilişskinin belirlenmesine yönelik olarak yapılmış olan çalışmalar neticesinde bir taraftan kamu tüketim harcamalarının büyüme üzerinde negatif etkisinin bulunduğu, diğer taraftan kamu yatırım harcamaları ile iktisadi büyüme arasında çok alt düzeyde bir ilişki bulunduğu yönünde ampirik bulgular elde etmiştir.

Thornton (1999) tarafindan yapılmış olan çalışmada Almanya'nın da içinde bulunduğu 6 gelişmiş ülke ekonomisi için Wagner Yasası'nın geçerliliğini sınamaya yönelik olarak yapılmış olan çalışma neticesinde ele alınan dönem için söz konusu 6 ülke ekonomisi açısından da kamu harcamaları ve iktisadi büyüme ilişkisinde Wagner Yasasını destekler nitelikteki bulgulara ulaşılmıştır.

Nelson ve Singh (1994) tarafından yapılan çalışmada farklı değişkenlerin iktisadi büyüme üzerindeki etkileri ortaya konulmaya çalışılmıştır. Çalışma kapsamında birisi 1970-1979 diğeri ise 1980-1989 yılları arası olmak üzere iki dönem için gelişmekte olan ülke olarak tanımlanan 70 ülkeye ait veriler kullanılmıştır. Çalışmada ülkelerin iktisadi büyüme hızını etkileyen etkenler arasında bütçe açıkları da ele alınmıştır. Ancak söz konusu ülkeler bakımından bütçe açıklarının iktisadi büyüme üzerinde etki yarattığına ilişkin belirli bir sonuca ulaşılamamıştır.

Günaydın (2000) tarafından Türkiye için 1950-1998 arasındaki dönemi kapsayacak şekilde toplam kamu harcamaları ve büyümeye ilişkin yıllık verileri kullanmak suretiyle Keynes ve Wagner Hipotezlerinin eş bütünleşme ile Granger 
nedensellik analizi çerçevesinde test edildiği çalışmada ele alınmış dönem için Wagner Yasası'nın geçerli olduğunu ortaya koyan bulgulara ulaşılmıştır.

Florio ve Colautti (2005) tarafindan Almanya'nın da aralarında bulunduğu 5 gelişmiş ülke ekonomisine ait veriler üzerinden kamu harcamaları ve iktisadi büyüme arasındaki ilişki incelenmiştir. Bu çalışmada 1870-1990 dönemine ilişkin veriler kullanılmış olup elde edilmiş olan bulgular ele alınan dönem itibariyle 5 ülke için Wagner Yasasını destekler nitelikte olmuştur.

Barışık ve Kesikoğlu (2006) tarafından yapılan çalışmada Türkiye'de bütçe açıklarının makroekonomik değişkenler üzerindeki eskileri Yapısal Olmayan Vektör Otoregresyon (VAR) yöntemiyle incelenmiştir. Bütçe açıklan, enflasyon, cari açık, istihdam, büyüme ve yatırım değişkenlerinden oluşan model 1987:Q12003:Q4 dönemi için tahmin edilmiştir. Elde edilen bulgular çerçevesinde Türkiye'de bütçe açıkları ile enflasyon, cari açık ve iktisadi büyüme arasında bir ilişkinin varlığı tespit edilmiştir. Konuyla ilgili olarak bu ilişkinin varlığını kuvvetlendirmek ve yönünü tespit etmek amaciyla Granger nedensellik testi gerçekleştirilmiştir. Netice itibarıyla bütçe açığı ile enflasyon, cari açık ve büyüme arasında çift yönlü nedensellik ilişkisinin olduğuna dair neticeler elde edilmiştir. Buna karşı1ık istihdamdan bütçe açıklarına ve büyümeden yatırıma doğru tek yönlü bir nedensellik ilişkisi tespit edilmiştir.

Oktayer ve Susam (2008) tarafından, Türkiye'ye ait 1970-2005 dönemini kapsayan veriler üzerinden kamu harcamaları ile iktisadi büyüme arasındaki ilişki ampirik olarak test edilmiştir. Çalışma neticesinde elde edilmiş olan bulgulara göre Türkiye ekonomisi için ele alınmış olan dönem açısından toplam kamu harcamalarının iktisadi büyüme üzerinde yarattığı etki anlamlı çıkmamıştır. Buna karşılık aynı bulgular çerçevesinde kamu yatırım harcamalarının iktisadi büyüme üzerinde olumlu bir etki ortaya çıkardığı sonucuna ulaşılmıştır.

Adak (2010) tarafından kamu açıklarının ekonomik büyüme üzerindeki muhtemel etkileri üzerine yapılan incelemede, 1972-2006 dönemini kapsayan ve en küçük kareler yöntemi ile yapılan analiz sonuçlarına göre ekonomideki yıllık bütçe açıklarının aynı yılın iktisadi büyüme düzeyinde olumsuz bir etki yarattığı neticesine ulaşılmıştır. Diğer taraftan bir dönemde ortaya çıkmış olan bütçe açığının takip eden dönemlerin iktisadi büyümesi üzerine etkisi de araştırılmasına rağmen istatistiksel olarak anlamlı sonuçlara ulaşılamamıştır. Bununla birlikte analiz sonucunda elde edilmiş olan model değerleri ile parametre değerlerinin istatistiksel anlamdaki sonuçlarının güvenilirlik sınırları içinde kaldığı gözlemlenmiştir.

Çavdar (2011) tarafından Türkiye' de 1994:Q1- 2004:Q4 dönemine ilişkin olarak bütçe açıklarında meydana gelecek bir artışın iktisadi büyümeye etkisi araştırılmıştır. Araştırma çerçevesinde Genişletilmiş Dickey Fuller (ADF) birim kök testiyle beraber standart Granger nedensellik testi uygulanarak bütçe açıkları 
ve iktisadi büyüme oranı arasındaki ilişki araştırılmıştır. Elde edilen ekonometrik bulgular 1şığında bütçe açıklarından iktisadi büyüme oranına doğru bir nedensellik ilişkisinin bulunduğu sonucuna varılmıştır (BAGSYH $\Rightarrow B O$ ). Burada ulaşılan sonuç, Keynesyen yaklaşımda "dişsal bir değişken" olarak kabul edilmiş olan kamu harcamalarının ekonomideki büyümeyi olumlu bir şekilde etkileyeceği yönündeki görüşünü destekler nitelikte olmuştur.

Oktayer (2011) tarafından, Wagner Yasası'nın Türkiye için geçerliliği 1950-2009 dönemi verileri kullanılmak suretiyle incelenmiştir. Eşbütünleşme ve vektör hata düzeltme yöntemleri vasıtasıyla yapılmış olan çalışma neticesinde elde edilmiş olan sonuçlar söz konusu dönem için Türkiye ekonomisi açısından Wagner Yasası'nı destekleyen nitelik arz etmektedir.

Turan, Berkman ve Akyıldız (2016) tarafından Türkiye'de 2006:Q1-2015:Q3 dönemine ilişkin olarak yapılmış olan çalışmada bütçe açıkları ve iktisadi büyüme serilerinin ADF testi sonucunda fark alma işlemiyle I(1) düzeyinde durağan oldukları görülerek yapılan Johansen eşbütünleşme testiyle değişkenler arasında uzun dönemli bir ilişkinin bulunduğu tespit edilmiştir. Granger nedensellik testinden elde edilen neticelere göre ise değişkenlerin arasında çift yönlü bir nedensellik bağının bulunduğu, bu çerçevede Türkiye ekonomisi için öncelikle Keynesyen yaklaşımın geçerli olduğu bulgusu elde edilirken sonrasında Wagner Yasası'nın da geçerli olduğu sonucuna ulaşılmıştır.

Yukarıda değinilmiş olan çalışmalar 1şı̆̆ında elde edilmiş olan ekonometrik verilerin yorumlanması neticesinde mutlak ve kesin bir yarg1 ortaya konulması sağlıklı bir yaklaşım olmayacaktır. Elbette böyle bir durumun ortaya çıkması bir bakıma normal karşılanmalıdır. Nitekim ele alınan ülke ve değişken sayısı ile dönem uzunluğu itibariyle veri sayısının daha önemlisi veri seti yapısının değişkenlik gösterdiği bu çalışmalarda zaman zaman birbirini destekleyen zaman zaman da birbirine karşit durum teşkil eden neticelere ulaşılmış olduğu görülmektedir.

Literatürde bulunan çalışmalara benzer şekilde bu çalışma kapsamında da bir ülkedeki iktisadi büyüme ile bütçe dengesi arasındaki ilişki ortaya konulmaya çalışılacaktır. Ancak burada sözü edilen ilişkinin somutlaştırılması sürecinde dolaylı ve dolaysız vergi tercihlerinde birbirinden önemli ölçüde farklılaştığı gözlemlenen iki ülkenin belirlenmiş olması ve söz konusu ilişkinin varlığının belirlenmiş dönem itibariyle bu anlamda irdelenmesi çalışmanın ayrıştığı bunun yanı sıra literatüre katkı sağlayacağı düşünülen noktaya işaret etmektedir.

\section{Model ve Veri Setine İlişkin Açıklamalar}

Bütçe dengesi ve iktisadi büyüme arasında Türkiye ve Almanya açısından irdelenmiş olan ilişkinin ekonometrik bulgularının elde edilmesinde Eviews 10 programından yararlanılmıştır. Söz konusu program vasıtasıyla elde edilen uzun 
dönem ve kısa döneme ait ekonometrik bulgular ülkelerin vergi sistemlerindeki dolaylı ve dolaysız vergi ağırlıkları çerçevesinde karşılaştırmalı olarak yorumlanmaya çalışılmıştır.

Veri seti olarak Türkiye ve Almanya için 1995-2016 yılları arasındaki 22 yıllık dönemi kapsayan (Şekil 1, Şekil 2, Şekil 3 ve Şekil 4'de yıllık bazda gösterilmiş olan) yıl bazındaki Bütçe Dengesi/GSYH oranı ile Reel GSYH Büyüme oranı kullanılmıştır. Burada belirtilmiş̧ olan her iki oran yüzde (\%) bazında değişimi yansitmaktadir.

\subsection{Birim Kök Testi}

Zaman serilerinde durağan ve durağan olmayan seriler arasında önemli farklılıklar bulunur. Durağan bir seride sabit bir ortalama, sabit bir varyans ve gecikme uzunluğu arttıkça teorik otokorelasyonun azaldığ görülür. Buna karşın durağan olmayan bir seride ise seriyi geri çevirecek uzun dönemli bir ortalama olmadığı, değişen varyans durumu ve teorik otokorelasyonun azalarak tamamen yok olmadığı görülür.

Bu noktada birim kök testi, geçmiş dönem değerlerinin seriyi ne yönde etkilediği üzerinden serinin durağan olup olmadığını belirler. Ekonometrik modelleme çalışmalarında literatürde geçerlilik bakımından kabul gören zaman serisi durağanlık testlerinin önde gelen bir tanesi de Dickey-Fuller tarafindan 1979 yllında geliş̧irilmiş olan birim kök testidir. $\mathrm{Bu}$ çalışmada da verilerin durağanlığının tespitinde Genişletilmiş Dickey-Fuller (Augmented Dickey FullerADF) birim kök testi kullanılacaktır.

Dickey-Fuller birim kök testi,

$\mathrm{Y}_{\mathrm{t}}=\mathrm{Y}_{(\mathrm{t}-1)}+\mathrm{u}_{\mathrm{t}}$

Şeklinde modellenmiş bulunmaktadır.

Dickey-Fuller testi için uygulanması gereken aşamalar şu şekilde gerçekleşir:

$\Delta \mathrm{Y}_{\mathrm{t}}=(\mathrm{\rho}-1) \mathrm{Y}_{(\mathrm{t}-1)}+\mathrm{u}_{\mathrm{t}}$

Denklemde $\delta=(\rho-1)$ olarak yerleştirilirse aşağıdaki denklem elde edilir.

$\Delta \mathrm{Y}_{\mathrm{t}}=\delta \mathrm{Y}_{(\mathrm{t}-1)}+\mathrm{u}_{\mathrm{t}}$

3 no'lu denklem sabit terimsiz ve trendsiz modeli yansitmaktadır. Bundan sonraki adımlarda denklemde yer alan katsayı dikkate alınarak hipotezler kurulmalıdır. $\mathrm{Bu}$ çerçevede serinin durağan olup olmadığı ile ilgili olarak aşağıdaki $H_{o}$ ve $H_{1}$ hipotezleri kurulur. Buna göre, 
$\mathrm{H}_{0}: \delta \geq 0$ Birim kök bulunduğu için veri durağan değildir.

$\mathrm{H}_{1}: \delta<0$ Birim kök bulunmadığg için veri durağandır.

Ancak Dickey-Fuller testi sadece 3 no'lu denklemde görüldüğü gibi test edilmez. Bazı durumlarda bu modeller bir sabit terim ve buna ilaveten zamansal bir eğilimi gösteren trend katsayısı da içerebilirler. Bu gösterimler de (4) ve (5) no'lu denklemler ile yansitılmaktadır:

$\Delta \mathrm{Y}_{\mathrm{t}}=\beta_{1}+\delta \mathrm{Y}_{(\mathrm{t}-1)}+\mathrm{u}_{\mathrm{t}} \quad($ Sabit Terimli ve Trendsiz $)$

$\Delta \mathrm{Y}_{\mathrm{t}}=\beta_{1}+\beta_{2} \mathrm{t}+\delta \mathrm{Y}_{(\mathrm{t}-1)}+\mathrm{u}_{\mathrm{t}} \quad$ (Sabit Terim ve Trendli)

Bazı durumlarda Dickey-Fuller testinde bulunan hata terimi, eş varyans varsayımını bozabilir ve değișen varyans özelliği gösterebilir veya ardışık bağımlı bir nitelik sergileyebilir Böyle bir durumun ortaya çıkması halinde yukarıda belirtilmiş olan sabit terimsiz ve trendsiz, sabit terimli ve trendsiz ile sabit terimli ve trendli olarak gösterilmiş olan denklemlerin, hata terimlerinin ardışık bağımlı olmasını engelleyecek kadar bağımlı değişkenin birincil farklarının bir veya birden fazla gecikmeli değerinin dâhil edilmesi suretiyle genişletilmesi gerekecektir. Bu durumda yeni model (6) no'lu denklemde görüldüğü üzere;

$\Delta \mathrm{Y}_{\mathrm{t}}=\beta_{1}+\beta_{2} \mathrm{t}+\delta \mathrm{Y}_{(\mathrm{t}-1)}+\alpha_{\mathrm{i}}+\mathrm{u}_{\mathrm{t}}$

şeklinde olacaktır.

\subsection{Sınır Testi ve Eşbütünleşme Analizi}

Analiz çerçevesinde elde edilen F istatistik değerleri Pesaran'ın alt kritik ve üst kritik değerleriyle karşılaştırılır (Pesaran, Shin ve Smith, 2001, ss. 300-301). Karşılaştırma neticesinde üç muhtemel durumdan birinin ortaya çıkması söz konusudur. Buna göre birinci olarak F istatistik değeri alt kritik değerinden küçük ise seriler eşbütünleşik değildir, ikinci olarak $\mathrm{F}$ istatistik değeri alt ve üst kritik değerleri arasında bulunuyorsa kararsız bir durum ortaya çıkar, son olarak F istatistik değeri üst kritik değerin de üstündeyse seriler arasında eşbütünleşmenin var olduğundan söz edilir.

Seriler arasındaki eşbütünleşme ilişkisi tespit edildikten sonra bunlar arasındaki uzun ve kısa dönem ilişkilerini belirlemek için çalışmada ARDL (Autoregressive Distribution Lag) modelinden yararlanılmıştır. Bu modelin seçilme nedeni ise modelin uygulanması noktasında tüm serilerin düzeyde durağan olmaması veya bu serilerin aynı derece fark işlemi uygulanarak durağan hale gelmeleri yönünde bir gereklilik bulunmamasıdır. Bir başka ifadeyle serilerden bir kısmı düzeyde durağanlığa sahip iken bir kısmı fark alınmak suretiyle durağanlık kazanıyor ise yine de ARDL modeli kullanılabilmektedir. Buna karşın böyle durumlarda bazı 
yaklaşımların (örneğin, Johansen eşbütünleşme yaklaşımı) kullanılması mümkün değildir.

\section{Uygulanan Yöntem Çerçevesinde EIde Edilen Ampirik Bulgular}

\subsection{Türkiye'ye İlişkin Bulgular}

\subsubsection{Birim Kök Testi Sonuçları}

Tablo 1'deki sonuçlara göre ADF birim kök testinin düzey değerleri sonuçlarına göre reel GSYH büyüme serisinin sabitli modeldeki t-istatistik değerinin $\% 1, \% 5$ ve \%10 kritik değerlerinden mutlak değer olarak daha büyük olması nedeniyle her üçünde de birim kök içermediği yani durağanlığa sahip olduğu görülmektedir. $\mathrm{Bu}$ durum Ho hipotezinin reddedilmesi $\mathrm{H}_{1}$ hipotezinin kabul edilmesi anlamına gelmektedir. Aynı serinin düzey değerlerinin trendli ve sabitli halinde ise $\% 5$ ve \%10 kritik değerlerinde durağanlığa sahip olunduğu görülmektedir.

Tablo 1: ADF Birim Kök Test Sonuçları

\begin{tabular}{|c|c|c|c|c|}
\hline Değişken & \multicolumn{4}{|c|}{ Seviye I(0) } \\
\hline \multirow{6}{*}{$\begin{array}{c}\text { Reel GSYH/ } \\
\text { Büyüme Oranı }(\%)\end{array}$} & \multicolumn{2}{|c|}{ Sabitli } & \multicolumn{2}{|c|}{ Trendli+Sabitli } \\
\hline & \multicolumn{2}{|c|}{$-4,115313$ (t-Statistic) } & \multicolumn{2}{|c|}{$-4,078551(\mathrm{t}-$ Statistic) } \\
\hline & $\% 1$ & $-3,788030$ & $\% 1$ & $-4,467895$ \\
\hline & $\% 5$ & $-3,012363$ & $\% 5$ & $-3,644963$ \\
\hline & $\% 10$ & $-2,646119$ & $\% 10$ & $-3,261452$ \\
\hline & Prob. & 0,0049 & Prob. & 0,0217 \\
\hline \multirow{13}{*}{$\begin{array}{c}\text { Bütçe Açı̆̆ı } \\
\text { (Bütçe Fazlası)/ } \\
\text { GSYH Oranı (\%) }\end{array}$} & \multicolumn{2}{|c|}{ Sabitli } & \multicolumn{2}{|c|}{ Trendli+Sabitli } \\
\hline & \multicolumn{2}{|c|}{$-1.289215(\mathrm{t}-$ Statistic) } & \multicolumn{2}{|c|}{$-3,014411(\mathrm{t}-$ Statistic $)$} \\
\hline & $\% 1$ & $-3,788030$ & $\% 1$ & $-4,532598$ \\
\hline & $\% 5$ & $-3,012363$ & $\% 5$ & $-3,673616$ \\
\hline & $\% 10$ & $-2,646119$ & $\% 10$ & $-3,277364$ \\
\hline & Prob. & 0,6146 & Prob. & 0,1539 \\
\hline & \multicolumn{4}{|c|}{ Birinci Fark I(1) } \\
\hline & \multicolumn{2}{|c|}{ Sabitli } & \multicolumn{2}{|c|}{ Trendli+Sabitli } \\
\hline & \multicolumn{2}{|c|}{$-3,933555$ (t-Statistic) } & \multicolumn{2}{|c|}{$-3,777939(\mathrm{t}-$ Statistic $)$} \\
\hline & $\% 1$ & $-3,808546$ & $\% 1$ & $-4,498307$ \\
\hline & $\% 5$ & $-3,020686$ & $\% 5$ & $-3,658446$ \\
\hline & $\% 10$ & $-2,650413$ & $\% 10$ & $-3,268973$ \\
\hline & Prob. & 0,0077 & Prob. & 0,0401 \\
\hline
\end{tabular}

Not: Genişletilmiş Dickey-Fuller testinde verilerin gecikme uzunluğu Schwarz Bilgi Kriterine göre belirlenmiştir.

Bir diğer seri olan Bütçe Açığı (veya Bütçe Fazlası)/GSYH'nin düzey değerlerinde gerek sabitli gerek trendli ve sabitli modeldeki t-istatistik değerinin $\% 1, \% 5$ ve $\% 10$ kritik değerlerinden mutlak değer olarak daha küçük olması 
nedeniyle her üçünde de birim kök içerdiği yani durağanlığa sahip olmadığı yine Tablo 1'de görülmektedir. Bu durum Ho hipotezinin reddedilmesine engel teşkil etmektedir. Serinin olasılık değeri her iki durumda da 0,05'in üzerinde bulunmaktadır. $\mathrm{Bu}$ durumda serinin birinci farkının alınması gerekliliği ortaya çıkmıştır. Birinci fark değerlerinde sabitli modeldeki t-istatistik değerinin \%1, \%5 ve \%10 kritik değerlerinden mutlak değer olarak daha büyük olması nedeniyle her üçünde de birim kök içermediği yani durağanlığa sahip olduğu görülmektedir. Trendli ve sabitli modelde ise \%1 kritik değeri dışındaki iki kritik değerde birim kök bulunmadığı dolayısıyla durağanlığa sahip olunduğu görülmektedir.

\subsubsection{Gecikme Uzunluğunun Tespit Edilmesi}

Gecikme uzunluğu verilerini yansitan Tablo 2'de maksimum gecikme uzunluğu 4 olarak alınmış olup AIC, SC ve HQ kriterleri çerçevesinde gecikme uzunluğunun karşılaştırmalı olarak minimum olduğu ve otokorelasyonun bulunmadığı en uygun gecikme uzunluğu birinci gecikme uzunluğu olarak görünmektedir.

Tablo 2: Gecikme Uzunluğu

\begin{tabular}{|c|c|c|c|}
\hline Lag & AIC & SC & HQ \\
\hline 1 & $8,962482^{*}$ & $9,259272^{*}$ & $9,003405^{*}$ \\
\hline 2 & 9,338920 & 9,833571 & 9,407126 \\
\hline 3 & 9,236195 & 9,928706 & 9,331683 \\
\hline 4 & 9,528265 & 10,41864 & 9,651035 \\
\hline AIC: Akaike Bilgi Kriteri (Akaike Information Criterion) \\
SC: Schwarz Bilgi Kriteri (Schwarz Information Criterion) \\
HQ: Hannan-Quinn Bilgi Kriteri (Hannan-Quinn Information Criterion) \\
Not: *n uygun gecikme uzunluğunu ifade etmektedir \\
\hline
\end{tabular}

\subsubsection{Eşbütünleşme Analizi}

Tablo 3'e bakıldığında, $\mathrm{F}$ istatistik değerinin $\% 1, \% 5$ ve $\% 10$ kritik değerler için Pesaran'ın belirtmiş olduğu üst sınır I(1) değerlerinin üstünde olduğu görülmektedir. Bu karşılaştırma neticesinde seriler arasında eşbütünleşme ilişkisi olduğu sonucuna varılmaktadır.

Tablo 3: Sınır Testi ve Eşbütünleşme Analizi

\begin{tabular}{|c|c|c|c|c|c|c|c|}
\hline \multirow{2}{*}{$\mathbf{k}$} & \multirow{2}{*}{ F İstatistiği } & \multicolumn{2}{|c|}{ Kritik Değerler \%1 } & \multicolumn{2}{c|}{ Kritik Değerler \%5 } & \multicolumn{2}{c|}{ Kritik Değerler \%10 } \\
\cline { 3 - 8 } & & $\begin{array}{c}\text { Alt Sınır } \\
\text { I(0) }\end{array}$ & $\begin{array}{c}\text { Üst Sınır } \\
\text { I(1) }\end{array}$ & $\begin{array}{c}\text { Alt Sınır } \\
\text { I(0) }\end{array}$ & $\begin{array}{c}\text { Üst Sınır } \\
\text { I(1) }\end{array}$ & $\begin{array}{c}\text { Alt Sınır } \\
\text { I(0) }\end{array}$ & $\begin{array}{c}\text { Üst Sınır } \\
\text { I(1) }\end{array}$ \\
\hline 1 & 16,42 & 4,94 & 5,58 & 3,62 & 4,16 & 3,02 & 3,51 \\
\hline
\end{tabular}

Not: k, bağımsız değişken sayısını göstermektedir. Kritik değerlere ilişkin alt sınır I(0) ve üst sınır I(1) değerleri Pesaran'a ait tablolardan olan CI(ii)'den edinilmiştir (Pesaran vd., 2001, s. 300). 


\subsubsection{Seriler Arası Uzun Dönem İlişkisi}

Seriler arasındaki uzun dönemli ilișkiyi gösteren Tablo 4'deki veriler çerçevesinde Türkiye'de bütçe açığının reel GSYH'ye oranı \%1 düzeyinde değiştiğinde iktisadi büyüme oranının da aynı yönlü olarak yaklaşı $\% 0,27$ düzeyinde değişmekte olduğu anlaşılmaktadır.

Tablo 4: ARDL (1,1) Modeli Uzun Dönem Katsayıları

\begin{tabular}{|c|c|c|}
\hline Değişkenler* & Katsayı & t-istatistiği \\
\hline BAGSYHT & 0,268063 & 1,389534 \\
\hline C & 5,858397 & 5,608266 \\
\hline
\end{tabular}

* BAGSYHT: Türkiye'de bütçe açı̆̆ının (bütçe fazlasının) reel GSYH'ye oranı (\%).

\subsubsection{Seriler Arası Kısa Dönem İlişkisi}

Seriler arasındaki kısa dönemli ilişkinin düzeyini ortaya koymak üzere oluşturulan ARDL yaklaşımına dayalı hata düzeltme modeli sonuçlarına göre hata teriminin sahip olduğu katsayının -1 ile 0 arasında olması gerekmektedir. Diğer taraftan olasılık değerinin de anlamlılığı sağlaması gerekir. Burada hata terimine ait olasılık 0,0001 olup istatistiki anlamlılık sağlanmaktadır. Bu anlamlılık 1şığında kısa dönemde meydana gelen dengeden sapmaların uzun dönemde ortadan kalkacağ1 söylenebilir. Hata terimi katsayısına göre bir dönemde, uzun dönem dengesinden görülebilecek sapmanın yaklaşık $\% 85^{\prime}$ i bir sonraki dönemde ortadan kalkacaktır.

Tablo 5: ARDL(1,1) Yaklaşımına Dayalı Hata Düzeltme Modeli

\begin{tabular}{|c|c|c|}
\hline Değişkenler & Katsayı & t-istatistiği \\
\hline BUYUMET(-1) & $-1,072270$ & $-6,625261$ \\
\hline BAGSYHT(-1) & 0,287436 & 1,279401 \\
\hline D(BAGSYHT) & 1,823458 & 5,690418 \\
\hline HATATERIMLERIT(-1) & $-0,854141$ & $-4,860270$ \\
\hline
\end{tabular}

Model çıktılarına göre Türkiye'de bütçe açı̆̆ının reel GSYH'ye oranı \%1 düzeyinde değiştiğinde iktisadi büyüme oranı da aynı yönlü olarak yaklaşı \%1,82 düzeyinde değişmektedir. Diğer taraftan bir önceki döneme ait bütçe açığının reel GSYH'ye oranının \%1 kadar değişmesi durumunda bunun bir sonraki dönem iktisadi büyüme oranına etkisi aynı yönlü olarak yaklaşık $\% 0,28$ düzeyinde olacağı görülmektedir. Bu göstergeler doğrultusunda sonraki dönem itibarıyla uzun dönem dengesine oldukça yaklaşıldığı anlaşılmaktadır. 


\subsection{Almanya’ya İlişskin Bulgular}

\subsubsection{Birim Kök Testi Sonuçları}

Tablo 6'da verilmiş olan ADF birim kök testi düzey değerleri sonuçlarına göre reel GSYH büyüme serisinin gerek sabitli gerekse de trendli ve sabitli halindeki tistatistik değerinin \%1, \%5 ve \%10 kritik değerlerinden daha küçük (mutlak değer olarak ise daha büyük) olması nedeniyle her üçünde de birim kök içermediği yani durağanlığa sahip olduğu görülmektedir. Diğer taraftan Bütçe Açı̆̆ı (Bütçe Fazlası)/GSYH serisinin düzey değerlerinde sabitli modeldeki t-istatistik değerinin $\% 1, \% 5$ ve $\% 10$ kritik değerlerinden mutlak değer olarak daha büyük olması nedeniyle her üçünde de birim kök içermediği yani durağanlığa sahip olduğu görülmektedir. Buna karşıllk serinin trendli ve sabitli halinde ise $\% 1$ kritik değer haricindeki diğer iki kritik değerde birim kök bulunmayıp durağanlığa sahip olunduğu anlaşılmaktadır.

Tablo 6: ADF Birim Kök Test Sonuçları

\begin{tabular}{|c|c|c|c|c|}
\hline Değişken & \multicolumn{4}{|c|}{ Seviye I(0) } \\
\hline \multirow{6}{*}{$\begin{array}{c}\text { Reel } \\
\text { GSYH/Büyüme } \\
\text { Oranı }(\%)\end{array}$} & \multicolumn{2}{|c|}{ Sabitli } & \multicolumn{2}{|c|}{ Trendli+Sabitli } \\
\hline & \multicolumn{2}{|c|}{$-4,908711$ (t-Statistic) } & \multicolumn{2}{|c|}{$-4,783594(\mathrm{t}-$ Statistic $)$} \\
\hline & $\% 1$ & $-3,808546$ & $\% 1$ & $-4,498307$ \\
\hline & $\% 5$ & $-3,020686$ & $\% 5$ & $-3,658446$ \\
\hline & $\% 10$ & $-2,650413$ & $\% 10$ & $-3,268973$ \\
\hline & Prob. & 0,0009 & Prob. & 0,0057 \\
\hline \multirow{6}{*}{$\begin{array}{c}\text { Bütçe Açı̆̆ı (Bütçe } \\
\text { Fazlası)/ GSYH } \\
\text { Oranı }(\%)\end{array}$} & \multicolumn{2}{|c|}{ Sabitli } & \multicolumn{2}{|c|}{ Trendli+Sabitli } \\
\hline & \multicolumn{2}{|c|}{$-3,872821$ (t-Statistic) } & \multicolumn{2}{|c|}{$-4,187107(\mathrm{t}-$ Statistic) } \\
\hline & $\% 1$ & $-3,788030$ & $\% 1$ & $-4,616209$ \\
\hline & $\% 5$ & $-3,012363$ & $\% 5$ & $-3,710482$ \\
\hline & $\% 10$ & $-2,646119$ & $\% 10$ & $-3,297799$ \\
\hline & Prob. & 0,0083 & Prob. & 0,0216 \\
\hline
\end{tabular}

Not: Verilerin gecikme uzunluğu Schwarz Bilgi Kriterine göre belirlenmiştir.

\subsubsection{Gecikme Uzunluğunun Tespit Edilmesi}

Burada maksimum gecikme uzunluğu 4 olarak alınmış olup AIC, SC ve HQ kriterlerine göre gecikme uzunluğunun karşılaştırmalı olarak minimum olduğu ve otokorelasyonun bulunmadığ en uygun gecikme uzunluğunun birinci gecikme uzunluğu olduğu Tablo 7'de yer alan verilerden anlaşılmaktadır. 
Tablo 7: Gecikme Uzunluğu

\begin{tabular}{|c|c|c|c|}
\hline Lag & AIC & SC & HQ \\
\hline \hline 1 & $8,036553^{*}$ & $8,333344^{*}$ & $8,077477^{*}$ \\
\hline 2 & 8,209977 & 8,704628 & 8,278183 \\
\hline 3 & 8,509572 & 9,202083 & 8,605060 \\
\hline 4 & 8,725267 & 9,615638 & 8,848037 \\
\hline
\end{tabular}

AIC: Akaike Bilgi Kriteri (Akaike Information Criterion)

SC: Schwarz Bilgi Kriteri (Schwarz Information Criterion)

HQ: Hannan-Quinn Bilgi Kriteri (Hannan-Quinn Information Criterion)

Not: *En uygun gecikme uzunluğunu ifade etmektedir.

\subsubsection{Eşbütünleşme Analizi}

Analiz neticelerini gösteren Tablo 8'e bakıldığında, F istatistik değerinin \%1, \%5 ve \%10 kritik değerler için Pesaran'ın belirtmiş olduğu üst sınır I(1) değerlerinin üstünde olduğu görülmektedir. Bu koşular altında seriler arasında eşbütünleşme ilişkisi olduğu sonucuna ulaşılmaktadır.

Tablo 8: Sınır Testi ve Eşbütünleşme Analizi

\begin{tabular}{|c|c|c|c|c|c|c|c|}
\hline \multirow{2}{*}{$\mathbf{k}$} & \multirow{2}{*}{ F İstatistiği } & \multicolumn{2}{|c|}{ Kritik Değerler \%1 } & \multicolumn{2}{c|}{ Kritik Dĕ̌erler \%5 } & \multicolumn{2}{c|}{ Kritik Değerler \%10 } \\
\cline { 3 - 8 } & & $\begin{array}{c}\text { Alt Sınır } \\
\text { I(0) }\end{array}$ & $\begin{array}{c}\text { Üst Sınır } \\
\text { I(1) }\end{array}$ & $\begin{array}{c}\text { Alt Sınır } \\
\text { I(0) }\end{array}$ & $\begin{array}{c}\text { Üst Sınır } \\
\text { I(1) }\end{array}$ & $\begin{array}{c}\text { AIt Sınır } \\
\text { I(0) }\end{array}$ & $\begin{array}{c}\text { Üst SInır } \\
\text { I(1) }\end{array}$ \\
\hline 1 & 8,11 & 4,94 & 5,58 & 3,62 & 4,16 & 3,02 & 3,51 \\
\hline
\end{tabular}

Not: k, bağımsız değişken sayısını göstermektedir. Kritik değerlere ilişkin alt sınır I(0) ve üst sınır I(1) değerleri Pesaran'a ait tablolardan olan CI(ii)'den edinilmiştir (Pesaran vd., 2001, s. 300).

\subsubsection{Seriler Arası Uzun Dönem İlişkisi}

Değişkenler arasındaki uzun dönemli ilişkiyi gösteren Tablo 9'dan anlaşılacağ1 üzere Almanya'da bütçe açığının reel GSYH'ye oranı \%1 düzeyinde değiştiğinde uzun dönemde iktisadi büyüme oranı da aynı yönlü olarak yaklaşık \%0,24 düzeyinde değişmektedir.

Tablo 9: ARDL(3,0) Modeli Uzun Dönem Katsayıları

\begin{tabular}{|c|c|c|}
\hline Değişkenler & Katsayı & t-istatistiği \\
\hline BAGSYHG & 0.239216 & 2.030674 \\
\hline C & 1.746229 & 6.554121 \\
\hline
\end{tabular}

* BAGSYHG: Almanya'da bütçe açığının (bütçe fazlasının) reel GSYH’ye oranı (\%). 


\subsubsection{Seriler Arası Kısa Dönem İlişkisi}

ARDL yaklaşımına dayalı hata düzeltme modeli sonuçlarına göre hata terimi katsayısının -1 ile 0 arasında olduğu ve hata teriminin olasılık değerinin 0,0007 olması dolayısıyla istatistiki anlamlılığın sağlanmakta olduğu görülmektedir. $\mathrm{Bu}$ sayede bir dönemde, uzun dönem dengesinden ortaya çıkan sapmalar sonraki dönemde telafi edilebilecektir.

Kisa dönem ilişkilerini ortaya koymak için oluşturulmuş olan ve Tablo 10'da görüldüğü üzere ARDL yaklaşımına dayalı hata düzeltme modeli çıktılarına göre Almanya'da bütçe açığının reel GSYH'ye oranı \%1 düzeyinde değiștiğinde iktisadi büyüme oranı da aynı yönlü olarak yaklaşık \%0,52 düzeyinde değişmektedir. Modelde yer alan hata terimine ait katsayı ise sonraki dönem itibariyle uzun dönem dengesine önemli ölçüde yaklaşıldığını ifade etmektedir.

Tablo 10: ARDL(3,0) Yaklaşımına Dayalı Hata Düzeltme Modeli

\begin{tabular}{|c|c|c|}
\hline Değişkenler* & Katsayı & t-istatistiği \\
\hline BUYUMEG(-1) & -2.184500 & -4.861292 \\
\hline BAGSYHG & 0.522567 & 2.000453 \\
\hline D(BUYUMEG(-1)) & 0.801046 & 2.663972 \\
\hline D(BUYUMEG(-2)) & 0.288262 & 1.287953 \\
\hline HATATERIMLERIG(-1) & -0.993035 & -4.116867 \\
\hline
\end{tabular}

\section{Sonuç}

Bir ülkede benimsenen kamu maliyesi politikaları çerçevesinde şekillenen dolaylı ve dolaysız vergi ağırlığı ekseninde bütçe dengesinin büyüme üzerindeki etkisinin örnek iki ülke üzerinden ele alındığı bu çalışmada, analize konu olan ülkelerden Türkiye'ye ilişkin elde edilen ekonometrik bulgulara göre bütçe dengesinin \%1'lik değişimi sonrasında bu değişimin iktisadi büyüme üzerindeki etki düzeyinin kısa ve uzun dönem itibarıyla birbirinden ayrışmakta olduğu görülmüştür. Nitekim Türkiye için bütçe dengesinde $\% 1$ düzeyinde ortaya çıkacak olan bir değişme kısa dönem temelinde aynı yönlü olarak bu dönem iktisadi büyümesine $\% 1,82$, bir sonraki yıl iktisadi büyümesine ise $\% 0,28$ oranında etki yaratmaktadır. Diğer taraftan Türkiye için bütçe dengesindeki \%1'lik değişmenin ülke iktisadi büyümesi üzerindeki etkisinin uzun dönemdeki görünümü ise yine aynı yönlü olarak \%0,27 olarak tespit edilmiştir.

Çalışmaya konu edilen bir diğer ülke olan Almanya'ya ilişkin elde edilen ekonometrik bulgulara göre ise bütçe dengesinin \%1'lik değişimi sonrasında bu değişimin iktisadi büyüme üzerindeki etki düzeyinin kısa ve uzun dönem 
itibarıyla farklılık göstermekle birlikte bu farklılığın Türkiye'dekine kıyasla daha düşük derecede olduğu söylenebilir. Nitekim Almanya'nın bütçe dengesinde \%1 düzeyindeki bir değişmenin kısa dönem temelinde aynı yönlü olarak bu dönem iktisadi büyümesine \%0,52 düzeyinde bir etkide bulunurken, bu etkinin uzun dönemde ise yine aynı yönlü olarak \%0,24 oranında gerçekleştiği görülmüştür.

Araştırmaya konu edilen Türkiye ve Almanya temelinde yapılmış olan çalışmalar neticesinde bütçe dengesinin iktisadi büyüme üzerinde etkili olduğunu gösteren ekonometrik bulgulara bu iki ülke bakımından ulaşılmıştır. Buna göre bütçe dengesinin iktisadi büyüme üzerindeki etkisi uzun dönemde, dolaylı-dolaysız vergi ağırlığı konusunda birbirinden farklı özellikler taşıyan Türkiye ve Almanya açısından benzerlik göstermektedir. Buna karş1lık bütçe dengesinin iktisadi büyüme üzerindeki kısa dönem etkisinde ise Türkiye ve Almanya açısından önemli farklılıklar bulunduğu elde edilen bulgular 1şı̆̆ında tespit edilmiştir.

Kısa dönem için Türkiye'de ortaya çıkmış olan görünüme bakıldığında bütçe açı̆̆ında yaşanan bir artış sonrasında iktisadi büyümenin, kamu harcamaları artarken kamu gelirlerinde aynı ölçüde artış yaşanmaması kaynaklı olarak aynı yıl tüketimindeki artıştan önemli destek aldığ 1 düşünülmektedir. Çünkü Türkiye ekonomisinde bütçe açığının artması bir anlamda kamu harcamaları artarken kamu gelirlerinin dolayısıyla bu gelirler arasında önemli bir ağırlığa sahip olan dolaylı vergilerin artmaması anlamına gelecek ki bu da kısa vadede özellikle de aynı yıl içerisindeki tüketime olumlu yansıyacaktır. Bu etki dolaysız vergi uygulamalarının ön plana çıkmış olduğu Almanya ekonomisinde görülmemektedir. Bunun en temel nedeni ise dolaysız vergilerdeki bir azalmanın aynı dönem tüketimi üzerinde dolaylı vergilere kıyasla yapısı ve özellikleri gereği çok daha zayıf bir etki yaratacak olmasıdır.

Elden edilmiş olan bulguların daha önce açıklanmış olan Keynesyen Hipotez ve Wagner Kanunu çerçevesinde de yorumlanması mümkündür. Buna göre bir ülke ekonomisinde, bütçe dengesinde ortaya çıkacak olan bir açık ya da mevcut bütçe açığının artması bir bakıma kamu harcamaları ve kamu gelirleri arasında harcamalar lehine bir değişime işaret etmektedir. Kamu harcamalarında gerçekleştirilecek bir artış sonrasında bütçe dengesinde ortaya çıkacak olan bir açık durumu ya da genişlemesi halinde gerek kısa dönemde gerekse de uzun dönemde ülkenin iktisadi büyümesi üzerinde olumlu bir etkilenme durumunun Türkiye ve Almanya açısından çalışmada ele alınmış olan 1995-2016 dönemi için söz konusu olduğu görülmektedir. Bu sonuç özellikle ekonominin daralma ve durağanlık dönemlerinde bütçe açığından kaçınmayarak öncelikle kamu harcamalarındaki artış aracılığıyla bu sürecin olumsuz etkilerini ortadan kaldırmayı ya da hafifletmeyi öneren Keynesyen Yaklaşımı destekler niteliktedir. 


\section{Kaynakça}

Adak, M. (2010). Kamu açıkları ve ekonomik büyüme: Türkiye örneği. Maliye Dergisi, 159, 233-243.

Akdoğan, A. (2007). Kamu maliyesi. Ankara: Gazi Kitabevi.

Barışık, S. ve Kesikoğlu, F. (2006). Türkiye'de bütçe açıklarının temel makroekonomik değişkenler üzerine etkisi (1987-2003 VAR, etki-tepki analizi, varyans ayrıştırması). Ankara Üniversitesi SBF Dergisi, 61(4), 5982.

Barro, R.J. (1991). Economic growth in a cross section of countries. Quarterly Journal of Economics, CVI (425), 407-443.

Çavdar, Ş.Ç. (2011). Türkiye'de bütçe açıklarının iktisadi büyüme ve istikrar üzerine etkileri (1994:Q1-2004:Q4). Elektronik Sosyal Bilimler Dergisi, 10 (37), 26-41.

Florio, M. ve Colautti, S. (2005). A logistic growth theory of public expenditures: a study of five countries over 100 years. Public Choice, 122(3-4), 355-93.

Günaydın, İ. (2000). Türkiye için Wagner ve Keynes hipotezlerinin testi. Íktisat, İsletme ve Finans Dergisi, 15 (175), 70-86.

Musgrave, R.A. (2004). Kamu maliyesi teorisi (O. Şener ve Y. Methibay, Çev.). Ankara: Asil Yayın Dağıtım. (1958)

Nelson, M.A. ve Singh, R.D. (1994). The deficit-growth connection: some recent evidence from developing countries. Economic Development and Cultural Change, 43(1), 167-191.

OECD, https://data.oecd.org/gga/general-government-deficit.htm (Erişim Tarihi: 9 Mart 2019).

OECD, Economic outlook no:102 november 2017, http://stats.oecd.org/ (Erişim Tarihi: 7 Mart 2019).

Oktar, S.A. (2010). Vergi hukuku. İstanbul: Türkmen Kitabevi.

Oktayer, A. (2011). Türkiye'de ekonomik büyüme ve kamu harcamaları arasındaki ilişkinin ampirik analizi: 1950 - 2009. Istanbul Üniversitesi Iktisat Fakültesi Mecmuast, 61(1), 261-282.

Oktayer, N. ve Susam, N. (2008). Kamu harcamaları-ekonomik büyüme ilişkisi: 1970-2005 yılları Türkiye örneği. Atatürk Üniversitesi İktisadi ve Idari Bilimler Dergisi, 22(1), 145-164.

Pesaran, M.H., Shin, Y. ve Smith, R.J. (2001). Bounds testing approaches to the analysis of level relationships, Journal of Applied Econometrics, John Wiley \& Sons, Ltd., 16(3), 289-326. 
Thornton, J. (1999). Cointegration, causality and Wagner's Law in 19th century Europe. Applied Economics Letters, 6(7), 413-416.

Turan, Z, Berkman, A.N. ve Akyıldız, A. (2016). Sosyo-ekonomik ve politik sorunlar çerçevesinde bütçe açıkları ile büyüme arasındaki nedensellik ilişkisi: Türkiye örneği (2006:Q1-2015:Q3). The Journal of Academic Social Science, 4(27), 32-45.

T.C. Hazine ve Maliye Bakanlığ1, https://www.hmb.gov.tr/bumko-ekonomikgostergeler (Erişim Tarihi: 19 Şubat 2019).

Uluatam, Ö. (2005). Kamu maliyesi. Ankara: İmaj Yayınevi. 


\section{The Effect of Budget Balance on Economic Growth on the Basis of Indirect-Direct Taxes: The Case of Turkey and Germany}

\section{Extended Abstract}

\section{Introduction}

Tax policies, which are the main financing instrument of public expenditures, may vary according to the level of development of countries. For developed countries, the fairness of the tax system is the primary objective. Therefore, tax policies show a direct tax-weighted structure. In developing countries, the need to create funds leads countries to more easily obtainable income. The tax system in these countries exhibits a structure that focuses on indirect taxes.

In general, direct taxes determined in line with the fiscal policy focus on the income and wealth elements of individuals and institutions. However, indirect taxes mainly focus on expenditures made by economic units. Naturally, there may be reasons for preferring indirect and direct taxes to each other in line with the needs of countries.

It is certain that the combination of indirect taxes and direct taxes applied in a country is an influential factor on the preferences of individuals in that country such as consumption, savings, investment and employment. These differences, which will emerge through taxation preferences, may have an impact on economic growth. As a matter of fact, an increase in indirect taxes will affect the consumption habits of individuals who make up that society. This will change both the desire to prefer substitutes and the saving habits. Similarly, an increase in direct taxes may reduce individuals' desire to save and invest and erode their desire to work and produce. The main reason for the emergence of this situation is that direct taxes make the income level and wealth elements the subject of tax. The effects of indirect and direct taxes are not limited to those mentioned here, but it can be said that the effects of direct taxes on economic growth in a country are broader than indirect taxes.

When the studies in the literature are examined, it is seen that there are researches dealing with the relationship between economic growth and budget balance in terms of more than one country in different periods. Similarly, in this study, the relationship between the economic growth in a country and the budget balance will be put forward. In order to materialize the relationship, two countries, which are observed to differentiate in direct and indirect tax preferences, are identified. Examining the existence of the said relationship for the specified period points to the point where the study will decompose and contribute.

\section{Method}

Turkey is the first country which have been studied. The share of indirect taxes in total tax revenues in Turkey is relatively quite high. Referring to OECD data, the weight of indirect taxes in the tax system in Turkey in the recent period is understood that further increase reaching $70 \%$ level. Germany is the second country examined. In the German tax system, direct taxes have a predominant appearance. When OECD data is analyzed, it is seen that the weight of indirect taxes in the tax system in Germany varies between $45 \%$ and $50 \%$ on average.

In this study, the effect of budget balance on growth in the context of indirect and direct tax weight shaped within the framework of public finance policies is discussed. The econometric findings were obtained by using the Autoregressive Distributed Lag (ARDL) model with budget balance and economic growth data covering the period 1995-2016 for both countries. 


\section{Results and Discussion}

The econometric findings is similar in terms of Turkey and Germany in the long term. On the other hand, significant differences were observed in the short-term effect. For Turkey, $1 \%$ change in budget balance has an effect of $1.82 \%$ on the same period growth and $0.28 \%$ in the next period. This effect is $0.27 \%$ in the long term. For Germany, $1 \%$ change in budget balance has an effect of $0.52 \%$ on the same period growth and $0.24 \%$ on the long term growth. According to the econometric findings, it is understood that budget balance has an effect on economic growth for both countries.

The impact of the budget balance to economic growth in the long term, Turkey and Germany are similar terms. In contrast, significant differences in terms of Turkey and Germany in the short term with the findings of which have been identified.

In Turkey, economic growth is positively affected by the increase in the budget deficit. However, according to econometric findings, this relationship is only valid in the short term. This may be due to the fact that public expenditures have increased while public revenues have not experienced the same increase. In this way, consumption level is considered to be positively affected in the same year. Because the increase in the budget deficit means that while public expenditures are increasing, public revenues (thus indirect taxes, which have a significant weight among these revenues) do not increase. This will have a positive impact on consumption in the short term, especially in the same year. This effect is not seen in the German economy, where direct taxation has come to the fore. The main reason for this is that a decrease in direct taxes will have a weaker effect on the consumption of the period compared to indirect taxes (due to its structure and characteristics).

\section{Conclusion}

The findings obtained can also be interpreted within the framework of the Keynesian Hypothesis and Wagner's Law. In a country's economy, a deficit in the budget balance or an increase in the current budget deficit indicates a change in favor of expenditures between public expenditures and public revenues. Such a situation in the short term and in the long term (for the 1995-2016 period which is discussed in terms of Turkey and Germany) has been shown to positively affect economic growth. This result supports the Keynesian Approach, which proposes to alleviate the negative effects of the process with the increase in budget deficit and public expenditures during the recession periods of the economy. 